\title{
UTICAJ PRIVATNOG ZDRAVSTVENOG OSIGURANJA NA MAKROEKONOMSKI AMBIJENT REPUBLIKE SRBIJE
}

\begin{abstract}
Rezime:
Osnovni cilj ovog rada je ocena mogućnosti za efikasno širenje tržišta privatnih zdravstvenih osiguranja na teritoriji Republike Srbije, i socijalni i ekonomski impakt koji bi ekspanzija ovog tržišta imala. Dobro privatno zdravstveno osiguranje, njegova dobra saradnja i partnerstvo sa državnim zdravstvenim osiguranjem, kao i uklanjanje birokratskih prepreka za širenje tržišta privatnog zdravstvenog osiguranja, doprineće boljem zdravstvenom sistemu, boljim uslugama u zdravstvu, povećanju zdravlja, radnih sposobnosti, bogatstva, a samim tim i ekonomije i socijalne strukture cele države. Imajući u vidu činjenicu da obavezno zdravstveno osiguranje u Republici Srbiji ne može da pruži sve usluge svima, što je slučaj i u većini zemalja na svetu, javlja se potreba za uvođenjem alternativnih oblika zdravstvenog osiguranja. Privatno zdravstveno osiguranje kao jedna alternativa, polako ulazi u sistem zdravstevne zaštite Republike Srbije, sa mogućnošću daljeg razvijanja i dostizanja mnogo većih dimenzija.

Ključne reči: zdravstveno osiguranje, privatno zdravstveno osiguranje, osiguravajuće kompanije.
\end{abstract}

\section{UVOD}

Pravo na zdravstvenu zaštitu je univerzalno ljudsko pravo i može se smatrati tekovinom savremenog drušva i oznakom da je društvo civilizovano. Stoga se u većini zemalja smatra obaveznim i ostvaruje se putem obaveznih vidova zdravstvenog osiguranja. Na njih se obavezuje sama država svojim propisima, kao dug koji se građanima vraća zbog njihovog državljanstva, plaćanja poreza i ostalih obaveza i dužnosti koje građani imaju prema državi (služenje vojske i slično). U najvećem broju slučajeva ovde je reč o osiguranjima koje osnovala sama država, ali nije retkost sresti ni osiguranja čiji su osnivači zdravstvene ustanove, grupe građana i sindikalne organizacije. lako se zdravstveno osiguranje koje pruža država danas smatra kao nešto najnormalnije i najočekivanije, nije uvek bilo tako. Nastanak zdravstvenog osiguranja i zdravstvene zaštite vezuje sa za radničke pokrete iz druge polovine devetnaestog veka. I danas u većini zemalja sindikati, putem svojih ovlašćenih predstavnika, igraju značajnu ulogu u stvaranju državne politike zdravstvenih osiguranja.

Imajući u vidu činjenicu da obavezno zdravstveno osiguranje u Republici Srbiji ne može da pruži sve usluge svima, što je slučaj i u većini zemalja na svetu, javlja se potreba za uvođenjem alternativnih oblika zdravstvenog osiguranja. Privatno zdravstveno osiguranje kao jedna alternativa, polako ulazi u sistem zdravstevne zaštite Republike Srbije, ali još uvek nije razvijeno na očekivani način. Upravo će u ovom radu jednim komparativnim postupkom biti sagledan uticaj razvoja privatnog zdravstvenog osiguranja na ukupan soscioekonomski razvoj Republike Srbije.

\section{METODE RADA}

Nakon završetka Drugog svetskog rata, većina istočnoevropskih zemanja potpala je pod uticaj SSSR-a i uvela socijalistički društveni sistem, a celokupni sistem zdravstvene zaštite i zdravstvenog osiguranja modelovan je prema sovjetskom modelu. Ovaj model je, sa druge strane, bio izgrađen prema ideji po kome je celokupno stanovništvo obuhvaćeno pravom na besplatnu zdravstvenu zaštitu po modelu obaveznog zdravstvenog osiguranja. Za to vreme u Engleskoj i Italiji funkcionisali su sistemi „Nacionalnih zdravstvenih službi“, kojima je bilo takođe, obuhvaćeno celokupno stanovništvo. To je jedan od sistema kojim se postiže da se formiraju stubovi odgovorne socijalne države.

\footnotetext{
${ }^{1}$ Visoka skola za menadzment i ekonomiju Kragujevac

${ }^{2}$ Univerzitet za posovne studije Banja Luka
} 
Metode koje će biti upotrebljene za analiziranje navedene problematike su komparativne, uporedno-pravne, sistemske i istorijsko komparativna metoda.

Osiguravajuće kuće su nakon Drgog svetskog rata uočile da je potencijalni profit narastao upravo u sektoru zdravstvenog osiguranja, pa se u visokorazvijenim zemljama, sve češće pojavljuju različiti oblici dobrovoljnog osiguranja. U najvećem broju slučajeva reč je o osiguranjima koja podrazumevaju veći obim i veći standard zdravstvenih usluga (tzv. paralelna zdravstvena osiguranja) i osiguranjima onih prava koja nisu obuhvaćena obaveznim zdravstvenim osiguranjem (tzv. dodatna zdravstvena osiguranja). Takođe, nisu retki ni takvi osiguravajući sistemi koji u potpunosti zamenjuju državna osiguranja. ${ }^{3}$

Međutim, ceo sistem zdravstvene zaštite ima nekoliko ozbiljnih poteškoća ispred sebe. Jedan od suštinskih problema s kojima se Evropa u celini suočava, jeste starenje stanovništva. Ova neprijatna okolnost je uslovila da se počne sa promenom razmišljanja u pravcu modela za osnovno obezbeđenje društva. Osnovni problem je u tome što je svake godine sve manje radno sposobnih osoba, a sa druge strane sve manje radnika uplaćuje u državne zdravstvene fondove. Težnja za produženje radnog veka,kao jedna od mera kojom se pokušava izbeći veliki broj penzionera, sprečava mnoge mlade ljude da stupe u radni odnos i postanu uplatioci u socijalne programe kao što je zdravstveno osiguranje. Dodatni problem u poslednjih pet godina predstavljaju i budžetski deficiti. Oni primoravaju vlade pogođenih zemalja na budžetska smanjenja, što opet sa svoje strane umanjuje kvalitet i raspoloživost državne zdravstvene zaštite. Kasnija razmatranja pokazuju da svi ovi izazovi, dovode do ozbiljnih posledica, i iniciraju razmišljanja o lančanim reakcijama koje svaka promena u lancu izaziva.

Naime, u starom sistemu, tokom većeg dela 20. veka, centralna Evropa je doživela, bilo pod uticajem socijalističkog modela, bilo pod uticajem sovjetskog modela, to da je skoro svaki građanin bio pokriven zdravstveni osiguranjem, u kome je postojao postupak preraspodele. U ovom postupku, aktivni zaposleni su plaćali određene doprinose državi koja je to preraspodeljivala na radno nesposobna lica (bolesne, stare, unesrećene, decu). Ovo se nazivalo "generacijskim ugovorom” i predstavljalo je bazu socijalnog osiguranja. ${ }^{4}$

Suština je bila u obaveznosti zdravstvenog osiguranja, kojim su se sprečavale malverzacije u sistemu zdravstevnog osiguranja što je podsticalo korisnike da razmišljaju u pravcu obaveznosti korišćenja ove usluge. Dakle, sam princip je bio da dobrostojeći, tj. oni koji imaju stalni izvor prihoda uplaćuju u fond zdravstvenog osiguranja za one koji su „manje srećni“ kako se kaže u anglosaksonskoj literaturi, tj. za one koji nemaju stalno primanje ili im je stlno primanje na minimumu.

Ovde se mora izvesti pravilan zaključak da je ovim sistemom celokupna privreda ostvarivala profit, i to u znatnoj meri. Glavna činjenica koju konzervativci i libertarijanci nisu nikada uvideli jeste da čak i najslabije plaćeni radnik može da dobije adekvatnu lekarsku negu i da bude, kao poreski obveznik, ponovo na raspolaganju i radno sposoban. Upravo je suprotno bilo nekada: mnogi radnici u staroj Britaniji, recimo, ili danas u SAD imali su velike šanse da u slučaju bolesti postanu nesposobni za rad ili da umru, i da tako oštete celo društvo za radnu snagu. Problem je u Velikoj Britaniji bio taj što poslodavci i država nisu nisu obraćali pažnju na to, jer su imali probleme sa visokim natalitetom, zbog čega su slali stanovnike u kolonije iz prenaseljenih britanskih gradova. Dakle, tada starenje stanovništva nije bio primaran problem, već je situacija bila nalik na one u islamskim zemljama, Africi ili Indiji, gde je mnoštvo mladog sveta, nekvalifikovane radne snage pa je i interes poslodavaca da uvedu zdravstveno osiguranje bio mali pošto je radne snage bilo u izobilju. Kao dodatni plus možemo navesti to što su ljudi i njihove porodice bili sačuvani. Očuvanje ljudskih života doprinelo je da se poveća potražnja za namirnicama, odećom, obućom, robom i uslugama, a to je opet izazvalo povratni efekat u kome je cela ekonomija dobila novi zamajac. Imati radnu snagu očuvanog zdravlja, koja želi da uživa u potrošačkim dobrima, znači imati potencijalnog potrošača, a to je interes svakog proizvođača i davaoca usluga što uslovljava razvoj potrošačkog društva i rast broja klijenata.

\section{REZULTATI}

Promene koje su se dogodile na prostorima Istočne Evrope 90-tih godina dvadesetog veka, posle početka tranzicije, drastično su poremetile društvenu koheziju i stabilnost većine država, što je ostavilo posledice do danas. Među ovim državama su i neke članice EU poput Rumunije, Bugarske, Letonije, Litvanije i drugih. Neke od najznačanijnijih promena tog perioda su:

- česte selidbe, rad u inostranstvu, iseljavanje zbog loših (pogoršanih) životnih uslova u matičnoj zemlji zbog procesa tranzicije ili prosto mobilnost radne snage u globalizovanom svetu;

\footnotetext{
${ }^{3}$ Folland, G. S., (2007) The Economocs of Health and Health Care, Upper Saddle River, New Jersey, Prentice-Hall Inc

${ }^{4}$ Rohrbach, W, „Socijalno osiguranje i privatno zdravstveno osiguranje“, Revija za pravo osiguranja, 1-2/2007, Beograd, 2007
} 
- ukidanje radnika na određeno vreme, i zamenjivanje honorarnim radnicima, na koje se ne plaćaju doprinosi;

- $\quad$ rastuće očekivanje života, i sve veći broj penzionera. Oni su isključivo primaoci nadoknade, a dodatno su skloniji bolestima. Procenat, tj. odnos radnika i penzionera je sve manji i sve više u korist penzionera;

- smanjenje nataliteta, opada broj lica koja plaćaju doprinose;

- smanjeni prihodi od socijalnog osiguranja.

U skoro svim sferama i u skoro svim zemljama došlo je do negativnih efekata reformi, a većina građana, osim krupnog biznisa, smatrala je i smatra ove reforme neprijateljskima po sebe.

lako je državna zdravstvena zaštita suštinski dobra i neophodna, ona ima i kontraefekat na krhku i globalizovanu svetsku privredu u kojoj su svi igrači na tržištu međusobno povezani i svaki udar se brzo prenosi. U globalizovanom svetu nema mogućnosti za izolaciju, a i nezamisliva je bez prekogranične saradnje. Svuda tamo gde je socijalno osiguranje definisano kao državni monopol, ili po nalogu države usporava ili sprečava jeftine privatne inicijative zdravstvenog servisa, ona na osetljiv način ometa mehanizam privrede, koji je danas nezamisliv bez prekograničnih aktivnosti. ${ }^{5}$

Međutim, danas se otvaraju nove mogućnosti u celoj priči oko zdravstvenih osiguranja. Pojavljuju se nove strukture stanovništva, bogatih građana i uspešnih pojedinaca, koji predstavljaju stručnjake nekog uspešnog preduzeća, ili menadžere nekog uspešnog preduzeća sa filijalama u inostranstvu. Ta preduzeća, koje plaćaju ogromne sume za poreze (a pritom hiljadama stanovnika širom raznih regiona daju radna mesta) imaju moćne pojedince kao svoje zaposlene, i kada oni postanu bolesni, najčešće ne žele da satima čekaju u državnim ambulantama (vreme je novac). Oni takođe nisu skloni da popunjavaju formulare i da se šetaju unaokolo, da bi posle toga dobili jeftine preparate. Pritom, ne žele da vode korespondenciju sa nacionalnim birokratama u socijalnim službama u domovini i zemlji zaposlenja, jer to zahteva mnogo vremena, a vreme je za njih najvažnije. Oni traže osiguravače koji rade internacionalno i transnacionalno. Ovakvi ljudi će rado platiti veću mesečnu premiju osiguranja da bi uštedeli vreme, i dobili najbolju uslugu za sebe. ${ }^{6}$

U naprednijim zemljama socijalno osiguranje sarađuje sa privatnim zdravstvenim osiguranjem, i to tako što uglavnom država plati osnovno zdravstveno osiguranje, dok privatno osiguranje snosi ostale troškove. Kako se u Austriji i Nemačkoj zakonski smatra da svako mora da bude osiguran, to znači da se država i privatnici „otimaju” oko visokoplatežnih pacijenata: advokata, notara, itd. U pogledu kvaliteta usluga, oni se takmiče, a ovo pomaže stvaranju konkurencije i napretku sveukupne zdravstvene zaštite.

Zanimljiv je fenomen „pacijenta ekstra klase” oko koga se takmiče i nadmeću privatna i socijalna osiguranja. Tokom godina se u Austriji sve više povećavao namet na ove pacijente, da bi na kraju oni plaćali nesrazmerno više od običnih pacijenata. 1995. godine je Ustavni sud Austrije doneo odluku da se od pacijenata ekstra klase naplate samo naknade u srazmeri sa viškom usluga, da se prava ekstra klase prenesu na privatne bolnice i sanatorijume, i da su javne bolnice prihvatile profil zahteva u pogledu minimuma komfora koji je preuzet iz privatnih bolnica.

\section{DISKUSIJA}

stvari?

Dolazimo i do glavnog pitanja, a to je: kakve će posledice biti po Srbiju u celom ovom razvoju

Postoje neke procene ekonomskih stručnjaka o ekonomskim kretanjima i one kažu da će Srbija u sledećih nekoliko godina ili decenija doživeti prilične strukturalne promene, među kojima su:

- povratak imućnih iz inostranstva

- doseljenici iz drugih regiona (kako Srbija postaje bogatija, psotaje interesantna kao imigrantska zemlja)

- doseljavanje stručnjaka i menadžera i članova porodica sa rastom investicija

$\mathrm{U}$ isto vreme, bitno će se promeniti i starosna struktura, osim na Kosovu. Broj stanovnika preko 60 godina će porasti, a broj mladih ispod 15 godina će se smanjiti. Mnoge zemlje Istočne Evrope imaju probleme slične prirode. Bugarska je izgubila za 20 godina od početka tranzicije čak dva miliona ljudi (od 9 miliona broj stanovnika je spao na 7 miliona!) uz najmanji natalitet u EU, gde je gora samo Estonija, koja izumire. Takođe, Riga, prestonica Letonije, iako jedan od najlepših gradova Evrope, stalno gubi stanovnike zato što je Letonaca sve manje, a ove države su prilično nacionalističke i relativno siromašne naspram drugih iz EU i nikako nisu poželjne destinacije za useljavanje.

- Ovo ima nekoliko uzroka:

- Odlazak bejbi-bum generacije u penziju

\footnotetext{
${ }^{5}$ Drechler D., Jutting J, „Different Countries, Different Needs: The Role of Private Health Insurance in Developing Countries“, Journal of Health Politics, Policy and Low, Volume 32, No. 3, 2007, pp. 497-534

${ }^{6}$ Skipper, D. H., Kwon, W. J., (2007) Risk Management and Insurance, Perspectives in a global economy, USA, UK, Australia, Blackwell Publishing
} 
- Sve kasnije stupanje u brak i majčinstvo

- Emotivne i seksualne slobode (odlučivanje na istopolne veze koje u Srbiji ne mogu da usvajaju decu niti da vrše veštačku oplodnju, ili odlučivanje za samački život)

- Duži životni vek starijih ljudi

- Mali natalitet

- Veliki procenat i broj abortusa

- i slično.

Koji god da su uzroci starenja stanovništva, može se primetiti jedan zanimljiv trend: u svetu se sve manje mladih obrazuje na način na koji su se obrazovali njihovi roditelji, i ponašaju se ravnodušno $i$ neambiciozno. Sasvim je moguće da se slično desi i u Srbiji i da se poveća broj moćnih i bogatih ljudi koji će biti stariji od 55 godina i koji će biti lideri u biznisu, imati dobre zarade ali biti skloniji bolestima. Ono što je karakteristika Evrope danas je da stariji izdržavaju mlade, kojima u celoj Evropi preti nezaposlenost. U Australiji, recimo, natalitet je veoma dobar, privreda je ekspanzivna, u zemlju se useljavaju ljudi i nema ovih opasnosti, ali Evropi preti posebna vrsta krize, a privatno zdravstveno osiguranje može biti deo rešenja.

U tom smislu je za Srbiju neophodno da se zanuje nova kultura zdravstvene zaštite. Potrebna je snažnija odgovornost i oblastima medicine, životnog stila i oblasti socijalne pomoći države. Kada se desetine hiljada bivših gastarbajtera doseli u starosti i penziji u Srbiju, oni mogu početi da diktiraju tržištu uslove, tj. da zahtevaju iste one uslove koje su imali u Nemačkoj, Švajcarskoj ili Austriji. Oni će zahtevati zdravstvenu i starosnu negu na visokom nivou, i rado će biti spremni da plate za svoja zdravstvena osiguranja, ukoliko osiguravajuće kuće koje nude zdravstveno osiguranje pokažu da imaju nemačkoaustrijski kvalitet osiguranja.[5] Osim unošenja kapitala u Srbiju, oni mogu uneti i standarde i redefinisati zemlju. Ovo se već dešava u Turskoj koja se uobličava po standardima kao Nemačka, iako sve manje pokazuje želju da formalno pristupi EU.

Novi izazov je faktor da se u svetu uočava masovna pojava, gotovo epidemija dijabetesa u svetu (oko 230 miliona ljudi, posebno u razvijenim zemljama, ima šećernu bolest, a računa se da će u svetu do 2025. godine uz porast od $2,5 \%$ godišnje, u svetu biti čak 380 miliona dijabetičara, a troškovi lečenja će dostiči 300 milijardi evra), kao i lečenje matičnim ćelijama. Sve ove oblasti će morati biti pokrivene nekim lečenjem, a malo je verovatno da će in socijalno osiguranje od strane države finansirati, pa i o njima treba misliti kao o mogućim poljima primene privatnog zdravstvenog osiguranja. ${ }^{7}$

Danas se sreću brojni izazovi za građane i državne strukture oko zdravstvenog osiguranja: kako učiniti da se osiguranje učini dostupnim svima, da svi budu zadovoljni, da bogatiji ne pate zbog loše usluge i čekanja, a siromašniji da ne pate zbog toga što je zdravstveno osiguranje skupo? Rešenje je najbolja moguća kombinacija sistema koja omogućuje dostupnost kvalitetne zdravstvene zaštite u okviru sigurnih i stabilnih finansijskih izvora zavisno od lokalnih uslova. Poznati dokument Svetske zdravstvene organizacije "Zdravlje za sve u 21. veku" obavezuje sve države članice da obezbede solidarnost i univerzalnu dostupnost zdravstvenog osiguranja, uz istovremeno savlađivanje troškova.

Budžetski deficiti su sve primetniji u velikom broju zemalja, a i Srbija se sa njim bori već godinama, s tim što je u poslednjoj godini postalo prilično nategnuto. Većina zemalja, pa i Srbija, pokazuje sve manju želju za ulaganjima u državne bolnice i zdravstvenu zaštitu. Istovremeni rast broja osoba koje mogu da sebi priušte bolju zdravstvenu nego putem privatnih osiguranja, postoji realna mogućnost za osiguravajuće kuće da se prošire na tržište zdravstvenog osigranja. Pa ipak, nasleđe socijalizma je snažno: većina ljudi ne želi privatno osiguranje zbog toga što misli da je država zaista dužna da se stara o njima i da je ulaganje dodatnog novca u nešto što bi trebalo da bude samo po sebi dato, čisto pogrešno trošenje novca. Stoga i rast tržišta osiguranja nije veliki kao što se to očekivalo. Isto tako, treba uzeti i sociološke motive: Srbija spada u zemlje sa veoma snažnom egalitarnom tradicijom, što je mentalitet koji se nepogrešivo može pratiti od Starih Slovena, koji su živeli u egalitarnom društvu, kao i Vikinzi. Upravo su zato nordijske zemlje i slovenske zemlje prilično sklone egalitarizmu, slabim privatnim incijativama i većim očekivanjima od države. Razlika je što se u protestantskim državama Skandinavije sreće mnogo jača horizontalna povezanost, solidarnost i ulaganje u državu, dok se kod nas često očekuje da država pomogne, a da se izbegavaju porezi i slično.

Ipak ovde postoje prostori za razna poboljšanja, fuzije i kombinovanje dva sistema zdravstvenog osiguranja. Imajući u vidu da je državna zaštita slaba ili barem sve slabija, onda bi se određenim promenama moglo doprineti da se, partnerstvom socijalnog i privatnog zdravstvenog osiguranja, dostigne bolja zaštita stanovništa u zdravstvu. Ovakva fuzionisana zaštita kao kombinacija dva sistema, državnog i privatnog, dala bi višestruku korist za stanovništvo i za samu državu. ${ }^{8}$ Kada bi se zdravstvena zaštita poboljšala, bila bi bolja i nada za ostanak u zemlji i manje iseljavanje u inostranstvo, zatim bi se povećao i životni vek stanovnika. Sa boljim zdravstvenim osiguranjem automatski se povećava zdravlje stanovnika i

\footnotetext{
${ }^{7}$ Rohrbach, W, „Evaluacija u osiguranju“, 12. Savetovanje Palić, april 2011, Udruženje za pravo osiguranja Srbije, Zbornik radova, 2011

${ }^{8}$ Čekerevac A, Zdravstvena zaštita u Srbiji - uslov socijalne sigurnosti, Socijalna misao, Vol. 14, br. 4, 2007,str. 29-48
} 
njihova radna sposobnost, i sa porastom radne sposobnosti teoretski će skočiti i njihova primanja. Zdravi ljudi imaju nameru da putuju, da troše na odeću, obuću, izlaske, da troše na nova dobra, hranu i slično. Oni su sa svojim primanjima zamajac privrede, a njihov zamajac je dobro zdravlje. Kada se obezbedi dobro zdravlje nacije, moći će se računati i na privredni oporavak, uz sve poštovanje makroekonomskih aspekata. A šta je zamajac dobrog zdravlja? Ništa drugo do dobra zdravstvena zaštita, tj. zdravstveno osiguranje. U ovoj oblasti, stoga, privatno zdravstveno osiguranje zasigurno igra veliku ulogu i može doprineti socijalnom i ekonomskom razvoju Republike Srbije. Na žalost, u Srbiji postoji neravnopravan položaj dobrovoljnih penzijskih fondova i dobrovoljnog zdravstvenog osiguranja, koji se ogleda u sledećem: premija za DZO u svim zemljama u okruženju ima poreske olakšice, a jedino u Srbiji ne. S druge strane, postoje odlični preduslovi za razvoj tržišta privatnog zdravstvenog osiguranja, a to su:

- Postoji ogromno interesovanje poslodavaca

- Ministarstvo zdravlja je zakonskim propisima definisalo okvire za razvoj dobrovoljnog zdravstvenog osiguranja u Srbiji

- Briga za zdravlje bi se, u slučaju veće prisutnosti privatnog zdravstvenog osiguranja na tržištu, sa države i pojedinca prebacila na poslodavca i osiguravajuće kompanije

- Takođe, smanjio bi se finansijski pritisak na RZZO i budžet Republike Srbije

U ovom periodu razvoja naše zemlje za razvoj dobrovoljnog zdravstvenog osiguranja treba tražiti prostor u tzv. kolektivnim osiguranjima, tj. osiguranjima sponzorisanim od strane poslodavaca, kao i kroz povećanje poreskih olakšica za participiranje u sistemu dobrovoljnog zdravstvenog osiguranja. S tim što bi istovremeno, i paket zdravstvenih usluga trebalo povećati. Nemaju ništa protiv toga ni osiguravači, ali pod uslovom da se privatan i državni sektor izjednače, čime će i oni ponuditi veći izbor. Tako bi građanin, između ostalog, mogao svog lekara da izabere i u državnom, i u privatnom domu zdravlja. ${ }^{9}$

Ukoliko bi se obezbedili uslovi za masovnije opredeljivanje stanovništva za lečenje u privatnom sektoru došlo bi do značajnog rasterećenja državnog fonda, a ujedno bi bilo omogućeno otvaranje novih radnih mesta za mlade lekare i za „višak” lekara iz državnih institucija. Pristupanje seoskih zdravstvenih stanica u sistem dobrovoljnog zdravstvenog osiguranja, motivisalo bi medicinsko osoblje da se zaposli u njima, pa bi se na ovaj način mogla obezbediti kvalitetna zdravstvena zaštita u onim sredinama u kojima to do sada nije bio slučaj. Pomenuto je od opštedruštvenog interesa, što znači da bi moralo da izazove pozitivnu reakciju i Ministarstva zdravlja i Republičkog zavoda za zdravstveno osiguranje, pre svega u vidu podrške osiguravajućem društvu.

\section{ZAKLJUČAK}

$\mathrm{U}$ poslednjih nekoliko godina u Srbiji su se značajno razvile privatne zdravstvene ustanove, od domova zdravlja do bolnica, i mnoge od njih mogu da odgovore na zahteve koje podrazumeva koncept izabranog lekara. Postojeći sistem primorava građane koji se leče u privatnom sektoru da usluge državnog sektora koriste samo radi, otvaranja bolovanja, dobijanja lekova na recept, potvrda o zdravstvenom stanju.

U ovom periodu razvoja naše zemlje za razvoj dobrovoljnog zdravstvenog osiguranja treba tražiti prostor u tzv. kolektivnim osiguranjima, tj. osiguranjima sponzorisanim od strane poslodavaca, kao i kroz povećanje poreskih olakšica za participiranje u sistemu dobrovoljnog zdravstvenog osiguranja. S tim što bi istovremeno, i paket zdravstvenih usluga trebalo povećati.

Nemaju ništa protiv toga ni osiguravači, ali pod uslovom da se privatan i državni sektor izjednače, čime će i oni ponuditi veći izbor. Tako bi građanin, između ostalog, mogao svog lekara da izabere i u državnom, i u privatnom domu zdravlja.

\section{LITERATURA}

1. Drechler D., Jutting J, „Different Countries, Different Needs: The Role of Private Health Insurance in Developing Countries“, Journal of Health Politics, Policy and Low, Volume 32, No. 3, 2007, pp. 497534;

2. Čekerevac A, Zdravstvena zaštita u Srbiji - uslov socijalne sigurnosti, Socijalna misao, Vol. 14, br. 4, 2007,str. 29-48;

3. Folland, G. S., (2007) The Economocs of Health and Health Care, Upper Saddle River, New Jersey, Prentice-Hall Inc.

4. Rakonjac-Antić T., Penzijsko i zdravstveno osiguranje, Centar za izdavačku delatnost, Ekonomski fakultet, Beograd, 2008;

5. Rohrbach, W, „Socijalno osiguranje i privatno zdravstveno osiguranje“, Revija za pravo osiguranja, 12/2007, Beograd, 2007; 
6. Skipper, D. H., Kwon, W. J., (2007) Risk Management and Insurance, Perspectives in a global economy, USA, UK, Australia, Blackwell Publishing.

7. Rohrbach, W, „Restrukturisanje i perspektive srpskog tržišta osiguranja“, Revija za pravo osiguranja, 3/2007, Beograd, 2007;

8. Rohrbach, W, „Evaluacija u osiguranju“, 12. Savetovanje Palić, april 2011, Udruženje za pravo osiguranja Srbije, Zbornik radova, 2011;

\section{Abstract}

The main objective of this work was to evaluate the possibilities for effective market expansion of private health insurance in the territory of the Republic of Serbia, and the social and economic impact of the expansion of this market had. Good private health insurance, its good cooperation and partnership with national health insurance, as well as the removal of bureaucratic obstacles to the expansion of private health insurance market, will contribute to better health services, better services in health, increase health, working ability, wealth, and therefore the economy and social structure of the entire state. Bearing in mind the fact that compulsory health insurance in the Republic of Serbia can not provide all services to all, as is the case in most countries of the world, there is a need for the introduction of alternative forms of health insurance. Private health insurance as an alternative, slowly enters the system of medical protection of the Republic of Serbia, with the possibility of further developing and achieving the much larger dimensions.

Key words: health insurance, private health insurance, the insurance company. 